\title{
Efek Ekstrak Etanol Daun Kelor (Moringa oleifera, Lamk.) Pada Mencit Model Demensia: Kajian Memori Spasial, Kadar Malondialdehid Dan Jumlah Sel Piramidal Hipokampus Area CA1 Dan CA2-CA3
}

\author{
Effect Of Kelor (Moringa oleifera, Lamk.) Leaf Ethanol Extract On \\ Demensia Mice Model: Spatial Memory Study, Malondialdehyde Levels \\ And Pyramidal Cell Hippocampus CA1 And CA2-CA3 Area
}

\author{
Arikha Ayu Susilowati, Gunawan Pamudji Widodo, Jason Merari \\ Program Studi Pasca Sarjana Jurusan Sains Fakultas Farmasi Universitas Setia Budi \\ Jl. Letjen Sutoyo No.6, Mojosongo, Jebres, Kota Surakarta, Jawa Tengah \\ Email: arikhasains2017@gmail.com
}

(Diterima : 2019-08-23, disetujui : 2019-11-27)

\begin{abstract}
ABSTRAK
Demensia adalah penyakit sel-sel saraf di otak, akibat hipokampus yang rusak oleh radikal bebas. EEDK (Ekstrak etanol daun kelor) (Moringa oleifera, Lamk.) mengandung phytochemicals, karoten, vitamin, mineral, asam amino, flavonoid dan phenolic, terbukti mengurangi kerusakan oksidatif dan defisit memori. Penelitian ini bertujuan mengetahui efek EEDK terhadap memori spasial, kadar MDA, jumlah sel piramidal hipokampus yang rusak area CA1,CA2-CA3 dan gambaran histopatologi mencit.

Rancangan penelitian ini pre test and post test control group design untuk uji memori spasial dan post test control group design untuk uji kadar MDA, jumlah sel piramidal hipokampus dan gambaran histopatologi. Menggunakan 30 ekor mencit terdiri dari 6 kelompok, per kelompok ada 5 ekor mencit, yaitu kelompok kontrol normal, kontrol positif, kontrol negatif, kelompok EEDK 100, 200, dan $400 \mathrm{mg} / \mathrm{kgBB}$, semua diinduksi $\mathrm{Pb}$ asetat $50 \mathrm{mg} / \mathrm{KgBB}$ kecuali pada kelompok normal. Kontrol positif diobati kuersetin $50 \mathrm{mg} / \mathrm{kgBB}$, sedangkan kontrol negatif tidak diobati. Data uji memori diperoleh dari uji Morris water maze pra dan paska perlakuan, data status antioksidan diperoleh dari uji kadar MDA dan data gambaran histopatologi diperoleh dari perhitungan jumlah sel pyramidal. Analisis data menggunakan repeated measures ANOVA dan ANOVA dengan Post Hoc LSD.

Hasil penelitian menunjukkan waktu latensi, uji kadar MDA dan pemeriksaan histopatologi otak terdapat perbedaan bermakna antara kelompok kontrol negatif dengan kelompok EEDK. Pemberian EEDK $400 \mathrm{mg} / \mathrm{kgBB}$ paling efektif memperbaiki memori spasial, menurunkan kadar MDA, dan mencegah kerusakan sel piramidal hipokampus area CA1, CA2-CA3.
\end{abstract}

Kata kunci : Moringa oleifera,Lamk., memori, antioksidan, hipokampus, dan Morris water maze

\section{ABSTRACT}

Dementia is a disease of nerve cells in the brain, due to the hippocampus damaged by free radicals. EEKL (Ethanol extract of kelor leaves)(Moringa oleifera, Lamk.) contains phytochemicals, carotene, vitamins, minerals, amino acids, flavonoids and phenolics, proven to reduce oxidative damage and memory deficits. This study aims to determine the effect of EEKL on spatial memory, MDA levels, the number of hippocampal pyramidal cells damaged in the CA1, CA2-CA3 area and histopathological features of mice.

The design of this study was pre-test and post-test control group design for spatial memory test and post test control group design for MDA levels, hippocampal pyramidal cell counts and histopathological features. This Reseach using 30 mice divided into of 6 groups, each group consist of 5 mice, namely the normal control group, positive control, negative control, EEKL group 100,200 , and $400 \mathrm{mg} / \mathrm{kg}$ body weight, all groups induced by Pb acetate $50 \mathrm{mg} / \mathrm{KgBW}$ except the normal group. Positive control was treated with quercetin $50 \mathrm{mg} / \mathrm{kgBW}$, while negative controls were not treated. Memory test data obtained from the Morris water maze pre and post- 
test, antioxidant status data obtained from MDA levels and histopathological data obtained from the calculation of pyramidal cell counts. Data analysis used repeated measures ANOVA and ANOVA with Post Hoc LSD.

The results showed that latency time, MDA level test and brain histopathology examination had significant differences between the negative control group and the EEKL group. EEKL 400 $\mathrm{mg} / \mathrm{kgBW}$ was most effective in improving spatial memory, decreasing MDA levels, and preventing damage to the hippocampal pyramidal cell CA1, CA2-CA3 area.

Key word : Moringa oleifera, Lamk., memory, antioxidant, hippocampus, Morris water maze

\section{PENDAHULUAN}

Demensia adalah suatu kemunduran intelektual (fungsi kognitif) berat dan progresif yang mengganggu fungsi sosial, pekerjaan, dan aktivitas harian seseorang (Assosiasi Alzheimer Indonesia, 2003). Gangguan fungsi kognitif dapat disebabkan oleh radikal bebas, yang memicu stres oksidatif yang merupakan patogenesis penting dalam perkembangan demensia (Butterfield et al, 2002). Stres oksidatif adalah ketidakseimbangan antara oksidan dan antioksidan dengan kadar oksidan yang lebih dominan. Oksidan adalah senyawa reaktif yang dapat memindahkan elektron dari molekul lain dan menghasilkan oksidasi pada molekul tersebut (Ayala A et al, 2014). Radikal bebas dapat ditangkal atau diredam dengan pemberian antioksidan atau dengan mengkonsumsi antioksidan (Halliwel, 2007). Salah satu tanaman yang berpotensi sebagai antioksidan eksogen di Indonesia adalah kelor (Moringa oleifera, Lamk) (Erika et al, 2014). Penelitian sebelumnya terhadap ekstraksi daun kelor menunjukkan adanya aktivitas antioksidan yang tinggi dalam proses in vivo dan in vitro, dalam daun kelor kaya akan phytochemicals, karoten, vitamin, mineral, asam amino, senyawa flavonoid dan phenolic (Anwar et al,
2007). Hasil penelitian sebelumnya membuktikan pengaruh daun Moringa oleifera dosis $180 \mathrm{mg}$ terhadap perbaikan memori dengan menggunakan metode Morris water maze (Illiandri et al, 2010). Oleh karena itu, ingin diteliti pengaruh ekstrak etanol daun kelor (Moringa oleifera) sebagai terapi alternatif perbaikan fungsi memori. Penelitian ini bertujuan untuk membuktikan efek pemberian ekstrak etanol daun kelor (Moringa oleifera) dalam memperbaiki memori spasial, penurunan kadar malondialdehid, penghambatan sel piramidal hipokampus yang rusak area CA1, CA2-CA3 dan gambaran histopatologi hipokampus mencit model demensia yang diinduksi $\mathrm{Pb}$ asetat.

\section{METODE PENELITIAN}

\section{Alat dan Bahan}

Uji memori, yang digunakan adalah alat tes Morris water maze, kamera video, stopwatch. Alat yang digunakan dalam pengukuran MDA adalah tabung reaksi, timbangan analitik merek sartorius, cawan porselen, gelas ukur, pengaduk elektrik, batang pengaduk dari kaca, sentrifuge, pHmeter merek Hanna, homogenizer (Potter-Elvehjem Tissue Grinders), vortex merek Genie, spektrofotometer UV-visibel merek 
Shimadzu. Dan pada pemeriksaan histopatologi alat yang digunakan adalah perlengkapan bedah, alat-alat gelas, dan Optilab untuk pemeriksaan preparat histopatologi dan perhitungan area CA1, CA2-CA3.

Bahan yang digunakan dalam penelitian ini adalah ekstrak etanol daun kelor (EEDK) dengan variasi dosis EEDK 100, 200 dan 400 mg/KgBB, dan sebagai pembanding adalah kuersetin, $\mathrm{Pb}$ asetat serta CMC Na 0,5\%.

\section{Pembuatan suspensi ekstrak etanol daun kelor}

Larutan pensuspensi adalah CMC$\mathrm{Na}$ 0,5\%. Larutan CMC-Na 0,5\% dibuat dengan menimbang 500 mg CMC-Na, digerus dalam mortir dengan sebagian air panas sedikit demi sedikit sampai larut, kemudian dimasukkan ke dalam labu takar sampai $100 \mathrm{ml}$. Sediaan uji dibuat dengan mensuspensikan ekstrak etanol daun kelor dalam larutan CMC-Na 0,5\%. Dibuat dengan tiga tingkatan dosis yaitu pada dosis 100 , 200, dan $400 \mathrm{mg} / \mathrm{KgBB}$.

\section{Pengelompokan Hewan Uji}

Kelompok I Kelompok normal diberikan CMC Na 0,5\%, kelompok II kontrol positif diberikan secara peroral kuersetin dengan dosis $50 \mathrm{mg} / \mathrm{KgBB}$, kelompok III kontrol negatif diberikan $\mathrm{Pb}$ asetat dosis $50 \mathrm{mg} / \mathrm{KgBB}$ secara intraperitoneal, kelompok IV EEDK 100 $\mathrm{mg} / \mathrm{KgBB}$ p.o, kelompok $\mathrm{V}$ EEDK 200 $\mathrm{mg} / \mathrm{KgBB}$ p.o, kelompok VI EEDK 400 $\mathrm{mg} / \mathrm{KgBB}$ p.o.

\section{Pengujian memori spasial dengan uji Morris water maze}

Hewan uji dilatih selama 3 hari, mencit dilatih berenang untuk mencari platform dan naik ke atas platform. Waktu yang dibutuhkan mencit untuk mencapai platform (waktu latensi). Setelah 3 hari latihan kemudian dilakukan uji Morris water maze selama 3 hari untuk menghitung nilai T0 (latihan). Pada hari ke 1 tes acquasition trial, hari ke 2 tes probe trial dan hari ke 3 uji sensoris motoris, hal ini untuk mengetahui kondisi awal (latihan) dari kemampuan kognitif mencit. Kemudian pada hari ke 4 mencit dimasukkan ke dalam Morris water maze kembali untuk menghitung nilai T1 (pra perlakuan) untuk di tes acquasition trial, hari ke 5 tes probe trial dan hari ke 6 dilakukan uji sensoris motoris, kemudian pada hari ke 7 semua kelompok mencit diinduksi dengan $\mathrm{Pb}$ asetat, kecuali pada kelompok normal, selain $\mathrm{Pb}$ asetat yang diinduksikan untuk kelompok positif diinduksi kuersetin p.o, kelompok perlakuan EEDK dosis 100, 200 dan $400 \mathrm{mg} / \mathrm{KgBB}$, sedangkan untuk kelompok negatif hanya diinduksi $\mathrm{Pb}$ asetat i.p. Perlakuan dilakukan selama 5 hari, selanjutnya dilakukan uji morris water maze untuk menghitung nilai T2 (pasca perlakuan), pada hari ke 12 tes uji acquasition trial, pada hari ke 13 tahap uji probe trial dan hari ke 14 tes uji sensoris motoris. Setelah perhitungan waktu T2 selesai maka mencit segera dikorbankan untuk diambil otaknya. Otak serebrum diiris menjadi dua, kemudian difiksasi dengan formalin $10 \%$.

\section{Uji Kadar Malondialdehid}

Untuk pengukukuran kadar malondialdehid cerebrum kiri difiksasi dengan formalin $10 \%$ untuk selanjutnya ditetapkan kadar malondialdehid di Laboratorium Pangan dan Gizi Universitas Gajah Mada, Jogjakarta. Uji 
kadar malondialdehid yang digunakan dalam penelitian ini adalah metode Thiobarbituric Acid Reactive Substance (TBARS) (Gupta et al, 2003). Nilai TBARS dinyatakan dalam satuan $\mathrm{nmol} / \mathrm{ml}$ MDA jaringan otak.

Perhitungan sel piramidal hipokampus yang rusak di area CA1 dan CA2-CA3 serta pengamatan histopatologi hipokampus

Cerebrum kanan difiksasi dengan formalin $10 \%$ kemudian dibuat preparat histopatologi dengan pengecatan hematoksilin eosin di Laboratorium Bagian Histologi Fakultas Kedokteran Universitas Sebelas Maret, Surakarta. Preparat yang sudah jadi kemudian diamati dibawah mikroskop dengan bantuan alat Optilab dengan perbesaran 400x, yang dihubungkan dengan komputer. Setelah mendapatkan sel piramidal area CA1 dan CA2-CA3, tampilan pada mikroskop difoto. Hasil foto digabungkan menggunakan program Adobe Photoshop CS4 sampai didapatkan tampilan sel piramidal area CA1 dan CA2-CA3 secara utuh kemudian dihitung jumlah sel piramidal area CA1 dan CA2-CA3.

\section{HASIL DAN PEMBAHASAN}

Tahap Acquasition trial

Acquasition trial sebagai tahap penggambaran proses pembelajaran (proses mengingat) mencit, didapatkan data waktu latensi, penurunan waktu latensi dan persentase penurunan waktu latensi mencit mencapai platform, yang selengkapnya tersaji dalam tabel 1.

Tabel 1. Waktu Latensi, Penurunan Waktu Latensi dan Persentase Penurunan Waktu Latensi pada Acquasition Trial

\begin{tabular}{lccccc}
\hline \multicolumn{1}{c}{ Kelompok } & $\begin{array}{c}\text { T0 } \\
\text { (detik) }\end{array}$ & $\begin{array}{c}\text { T1 } \\
\text { (detik) }\end{array}$ & $\begin{array}{c}\text { T2 } \\
\text { (detik) }\end{array}$ & $\begin{array}{c}\text { Penurunan } \\
\text { Waktu } \\
\text { Latensi (T2- } \\
\text { T1) } \\
\text { (detik) }\end{array}$ & $\begin{array}{c}\text { Persentase } \\
\text { Penurunan } \\
\text { Waktu } \\
\text { Latensi (\%) }\end{array}$ \\
\hline Kontrol normal & 27,17 & 26,47 & 25,67 & $0,80 \pm 0,05^{\mathrm{c}}$ & $1,23 \pm 0,33^{\mathrm{c}}$ \\
\hline Kontrol positif & 25,54 & 22,90 & 22,64 & $0,26 \pm 0,04^{\mathrm{c}}$ & $3,44 \pm 1,38^{\mathrm{c}}$ \\
\hline Kontrol negatif & 26,39 & 24,69 & 28,92 & $-4,23 \pm 0,31^{\mathrm{a}, \mathrm{b}}$ & $-35,04 \pm 9,13^{\mathrm{a}, \mathrm{b}}$ \\
\hline EEDK100 $\mathrm{mg} / \mathrm{KgBB}$ & 30,00 & 23,84 & 22,69 & $1,15 \pm 0,25^{\mathrm{c}}$ & $3,16 \pm 2,28^{\mathrm{c}}$ \\
\hline EEDK200 $\mathbf{~ m g / K g B B}$ & 28,90 & 24,67 & 24,33 & $0,37 \pm 0,04^{\mathrm{c}}$ & $2,76 \pm 1,86^{\mathrm{c}}$ \\
\hline EEDK400 $\mathbf{~ m g / K g B B}$ & 27,12 & 25,30 & 24,35 & $0,95 \pm 0,03^{\mathrm{c}}$ & $1,18 \pm 0,43^{\mathrm{c}}$ \\
\hline Keterangan:
\end{tabular}

Keterangan: a=berbeda bermakna terhadap kontrol normal, $b=$ berbeda bermakna terhadap kontrol positif, $\mathrm{c}=$ berbeda bermakna terhadap kontrol negatif.

Berdasarkan analisisis statistika repeated measured ANOVA data penurunan waktu latensi tahap acquisition trial $(p=0,367)>0,05$, sedangkan uji levene menunjukkan nilai signifikasi $(p=0,07)>0,05)$, menunjukkan keenam kelompok berbeda tidak bermakna. Pada repeated measured 
ANOVA untuk data persentase penurunan waktu latensi $(p=0,447)>0,05$, menunjukkan data terdistribusi normal, uji Levene nilai signifikasinya $\quad(p=0,00)<0,05$, menunjukkan data tidak homogen sehingga dilanjutkan ke uji Tamhane. Untuk data penurunan waktu latensi karena homogen maka dilanjutkan ke uji LSD. Pada uji Tamhane dan LSD terdapat perbedaan bermakna antara kelompok kontrol negatif dengan kelompok kontrol normal menunjukkan pemberian $\mathrm{Pb}$ asetat $50 \mathrm{mg} / \mathrm{KgBB}$ dapat menurunkan fungsi belajar pada mencit. Sesuai dengan beberapa penelitian yang telah menunjukkan bahwa $\mathrm{Pb}$ disimpan dalam tubuh terutama oleh kompartemen seperti darah, jaringan lunak dan tulang. Jaringan lain yang menyimpan $\mathrm{Pb}$ termasuk otak, hati, limpa, ginjal, dan paru-paru (Owolabi, 2014). Pada penelitian Meng et al (2016) paparan $\mathrm{Pb}$ ini dapat menyebabkan kematian sel-sel di hippocampus dan mengakibatkan gangguan pada memori spasial.
Pada kelompok kontrol negatif dan kelompok kontrol positif menunjukkan perbedaan bermakna. Hal ini sesuai dengan penelitian Kale et al (2018) bahwa kuersetin menunjukkan perlindungan saraf yang signifikan setelah cedera otak akibat radiasi. Kuersetin diketahui dapat menghambat radikal oksigen dengan cara mendonorkan atom hidrogen atau elektron kepada radikal bebas. Kuersetin berperan sebagai antioksidan dengan cara mendonasikan atom hidrogennya atau melalui kemampuannya mengkelat logam beracun, berada dalam bentuk glukosida (mengandung rantai samping glukosa) atau dalam bentuk bebas yang disebut aglikon (Bhagwat et al, 2014).

Profil persentase daya perbaikan waktu latensi pada acquisition trial gambar 1, menunjukkan peningkatan dosis ekstrak etanol daun kelor searah dengan daya perbaikan waktu latensi pada tahap acquisition trial. Semakin

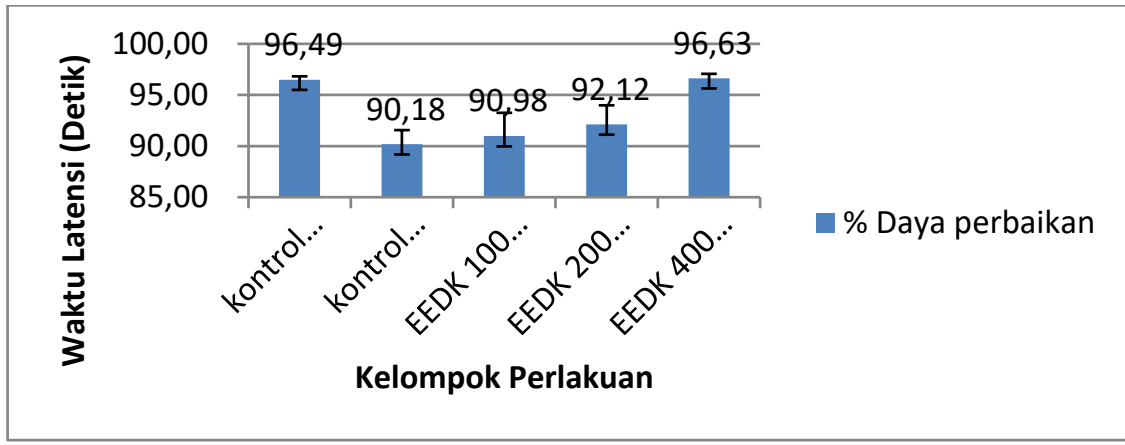

\section{Gambar 1. Profil persentase daya perbaikan waktu latensi pada acquisition trial}

tinggi dosis ekstrak etanol daun kelor maka persentase daya perbaikan waktu latensi semakin besar sehingga mengakibatkan waktu latensi mencit untuk mencapai platform lebih cepat. Hasil ini sesuai dengan Kirisattayakul et al (2013) menunjukkan ekstrak hidroalkohol dari daun kelor dengan 
dosis oral $100-400 \mathrm{mg} / \mathrm{kg}$ selama 3 minggu, diyakini menurunkan stres oksidatif dan peroksidasi lipid otak pada kerusakan otak yang disebabkan oleh iskemia serebral. Ekstrak etanol daun kelor menambah potensial kognitif dan sebagai neuroprotektan terhadap model hewan tikus yang diinduksi demensia (cholinotoxin secara intracerebroventricular) (Sutalangka et al, 2013).

\section{Tahap Probe trial}

Uji yang dilakukan untuk melihat fungsi memori hewan uji terutama kemampuan penyimpanan memori spasial mencit setelah fase pembelajaran pada acquisition trial. Data waktu latensi, peningkatan waktu latensi dan persentase peningkatan waktu latensi pada tahap probe trial dapat dilihat pada tabel 2 .
Data peningkatan waktu latensi dan persentase peningkatan waktu latensi terdistribusi normal dan homogen, dengan nilai signifikasi data peningkatan waktu latensi $(p=0,242)>0,05$ dan uji levene menunjukkan nilai signifikasi $(p=0,450)>0,05$, untuk data persentase peningkatan waktu latensi $(p=0,292)>0,05$ dan uji Levene dengan nilai signifikasinya $(p=0,152)>0,05$, Kemudian masing-masing dilanjutkan uji LSD, dengan hasil ada perbedaan bermakna pada data peningkatan waktu latensi dan persentase waktu latensi antara kelompok normal dan kelompok kontrol negatif yang menunjukkan bahwa pemberian $\mathrm{Pb}$ asetat dapat menyebabkan terjadinya gangguan pada fungsi memori.

Tabel 2. Waktu Latensi, Peningkatan Waktu Latensi dan Persentase Peningkatan Waktu Latensi pada Probe Trial

\begin{tabular}{|c|c|c|c|c|c|}
\hline Kelompok & $\begin{array}{c}\text { T0 } \\
\text { (detik) }\end{array}$ & $\begin{array}{c}\text { T1 } \\
\text { (detik) }\end{array}$ & $\begin{array}{c}\text { T2 } \\
\text { (detik) }\end{array}$ & $\begin{array}{l}\text { Peningkatan } \\
\text { waktu latensi } \\
\text { (detik) }\end{array}$ & $\begin{array}{c}\text { Persentase } \\
\text { Peningkatan } \\
\text { Waktu Latensi } \\
(\%)\end{array}$ \\
\hline Kontrol normal & 5,86 & 6,39 & 7,17 & $0,79 \pm 0,03^{c}$ & $11,36 \pm 2,83^{c}$ \\
\hline Kontrol positif & 3,88 & 4,18 & 5,63 & $0,75 \pm 0,02^{c}$ & $25,97 \pm 10,87^{c}$ \\
\hline Kontrol negatif & 5,04 & 6,96 & 4,07 & $-3,53 \pm 0,98^{a, b}$ & $71,15 \pm 7,19^{a, b}$ \\
\hline EEDK $100 \mathrm{mg} / \mathrm{KgBB}$ & 3,40 & 6,48 & 6,19 & $0,33 \pm 0,04^{c}$ & $32,07 \pm 10,37^{c}$ \\
\hline EEDK $200 \mathrm{mg} / \mathrm{KgBB}$ & 3,58 & 5,37 & 6,18 & $0,90 \pm 0,01^{c}$ & $27,52 \pm 1,15^{\mathrm{c}}$ \\
\hline EEDK $400 \mathrm{mg} / \mathrm{KgBB}$ & 4,08 & 4,31 & 6,34 & $1,95 \pm 0,04^{c}$ & $24,90 \pm 3,92^{c}$ \\
\hline
\end{tabular}

Keterangan: :[-]=ada peningkatan waktu latensi, a=berbeda bermakna terhadap kontrol normal, $b=$ =berbeda bermakna terhadap kontrol positif, $c=$ berbeda bermakna terhadap kontrol negatif

Paparan $\mathrm{Pb}$ sebelum dan sesudah kelahiran pada tikus bisa merusak kemampuan memori jangka pendek dan jangka panjang serta ultrastruktur hippocampal (Xu et al, 2009). Penelitian Liu et al (2015) menunjukkan bahwa paparan $\mathrm{Pb}$ dapat memicu microgliosis abnormal dan astrogliosis pada 
hipokampus tikus muda, yang kemudian dapat mengganggu neurogenesis hipokampus. Lemaire et al (2000) menyebutkan bahwa neurogenesis berhubungan dengan kemampuan belajar.

Dari uji LSD masing-masing data juga didapatkan perbedaan bermakna antara kelompok kontrol negatif dengan kelompok kontrol positif. Pemberian kuersetin $50 \mathrm{mg} / \mathrm{kgBB}$ dapat meningkatkan fungsi memori mencit yang diinduksi $\mathrm{Pb}$ asetat. Kuersetin merupakan golongan flavonoid, dilaporkan mempunyai aktivitas antioksidan karena kemampuan menangkap radikal bebas dan Reactive Oxygene Species (ROS) seperti anion superoksida dan radikal hidroksil (Morikawa et al, 2003; Schmalhausen et al, 2007). Kuersetin akan mengikat spesies radikal bebas sehingga dapat mengurangi reaktivitas radikal bebas tersebut. Pada gambar 2 peningkatan dosis ekstrak etanol daun kelor berpengaruh terhadap daya perbaikan waktu latensi. Sesuai dengan penelitian Hannan et al (2014) menunjukkan dalam penelitiannya tentang sifat pelindung saraf dari ekstrak etanol daun kelor saat diinkubasi pada kultur utama neuron hippocampal.

Hippocampus dorsal memainkan peran penting dalam pengambilan, pemrosesan memori jangka pendek dan mentransfer memori ke memori jangka panjang (Bannerman et al, 2002; Moser and Moser, 1998; Lee and Kesner, 2003). Radikal bebas menyebabkan terjadinya lesi di area ini sehingga menyebabkan masalah tentang navigasi yang diarahkan pada tujuan dan merusak kemampuan untuk mengingat lokasi yang tepat (Hebert and Dash, 2004).

Tahap Sensoris-motoris

uji sensori-motorik untuk melihat kemampuan mencit dalam berenang atau kemampuan motoris mencit, kemampuan indra penglihatannya sebagai kemampuan sensorik, dan motivasi mencit untuk keluar dari air sebagai faktor yang akan mempengaruhi kecepatan berenang mencit.

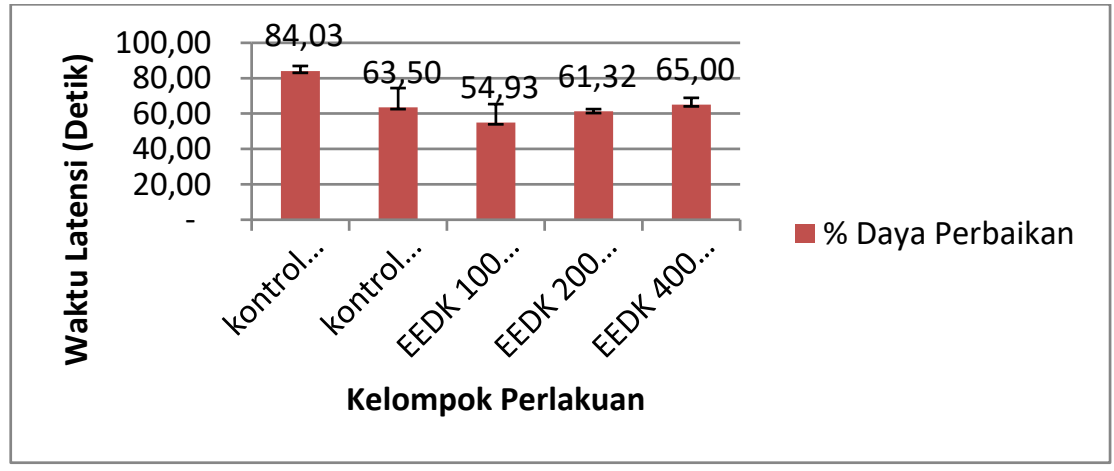

Gambar 2. Profil persentase daya perbaikan waktu latensi pada probe trial Tabel 3. Waktu Latensi, Penurunan Waktu Latensi dan Persentase Penurunan Waktu Latensi pada Uji Sensoris Motoris 


\begin{tabular}{lccccc}
\hline \multicolumn{1}{c}{ Kelompok } & $\begin{array}{c}\text { T0 } \\
\text { (detik) }\end{array}$ & $\begin{array}{c}\text { T1 } \\
\text { (detik } \\
\text { ) }\end{array}$ & $\begin{array}{c}\text { T2 } \\
\text { (detik } \\
\text { ) }\end{array}$ & $\begin{array}{c}\text { Penurunan } \\
\text { waktu latensi } \\
\text { (detik) }\end{array}$ & $\begin{array}{c}\text { Persentase } \\
\text { Penurunan Waktu } \\
\text { Latensi (\%) }\end{array}$ \\
\hline Kontrol normal & 18,85 & 17,01 & 14,59 & $2,42 \pm 1,45^{\mathrm{c}}$ & $14,32 \pm 4,37^{\mathrm{c}}$ \\
\hline Kontrol positif & 19,07 & 17,36 & 14,59 & $2,77 \pm 1,56^{\mathrm{c}}$ & $16,67 \pm 9,23^{\mathrm{c}}$ \\
\hline Kontrol negatif & 19,24 & 17,54 & 21,58 & $-4,04 \pm 0,55^{\mathrm{a}, \mathrm{b}}$ & $-23,11 \pm 4,35^{\mathrm{a}, \mathrm{b}}$ \\
\hline EEDK $100 \mathrm{mg} / \mathrm{kgbb}$ & 19,29 & 18,59 & 16,16 & $3,43 \pm 0,95^{\mathrm{c}}$ & $18,39 \pm 4,35^{\mathrm{c}}$ \\
\hline EEDK $200 \mathrm{mg} / \mathrm{kgbb}$ & 18,92 & 18,06 & 16,00 & $3,07 \pm 0,48^{\mathrm{c}}$ & $17,02 \pm 2,79^{\mathrm{c}}$ \\
\hline EEDK $400 \mathrm{mg} / \mathrm{kgbb}$ & 19,49 & 17,05 & 15,15 & $2,87 \pm 0,94^{\mathrm{c}}$ & $16,73 \pm 5,13^{\mathrm{c}}$ \\
\hline
\end{tabular}

Keterangan:[-]=ada penurunan waktu latensi, a=berbeda bermakna terhadap kontrol normal, $b=$ =berbeda bermakna terhadap kontrol positif, $c=$ berbeda bermakna terhadap kontrol negatif.

Pada penelitian (Mello et al, 1998) menunjukkan bahwa intoksikasi $\mathrm{Pb}$ asetat dapat menyebabkan perubahan yang menyimpang terhadap perkembangan perilaku hewan uji. Data waktu latensi, penurunan waktu latensi dan persentase penurunan waktu latensi tahap uji sensori motoris dapat dilihat pada tabel 3. Berdasarkan analisisis statistika repeated measured ANOVA data uji sensoris-motoris penurunan waktu latensi $(p=0.244)>0,05$, sedangkan uji levene menunjukkan nilai signifikasi $(p=0,251)>0,05$ menunjukkan keenam kelompok berbeda tidak bermakna dan terdapat perbedaan waktu latensi antar kelompok perlakuan tetapi semua mencit pada masing-masing kelompok dapat menemukan platform. Hal ini menunjukkan bahwa semua mencit di semua kelompok menunjukkan tidak ada gangguan sensori-motorik dan kondisi fisik mencit yang baik.

Pada gambar 3, menunjukkan peningkatan dosis ekstrak etanol daun kelor berpengaruh terhadap persentase daya perbaikan waktu latensi mencit untuk menemukan tanda di area platform. Bakre et al (2013) pada penelitiannya telah menunjukkan ekstrak etanol daun kelor memiliki aktivitas depresan dan antikonvulsan pada sistem saraf pusat

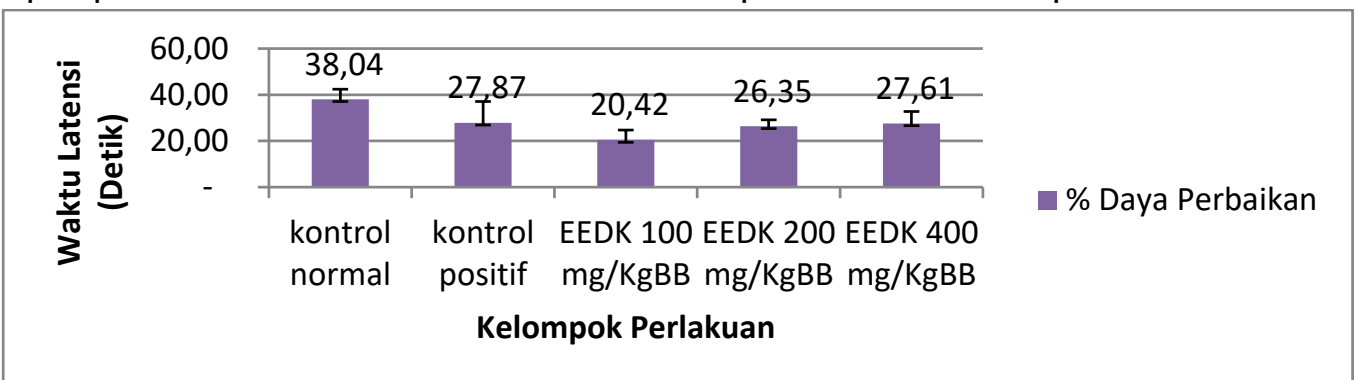

Gambar 3. Profil persentase daya perbaikan waktu latensi pada uji sensorimotoris

tikus melalui peningkatan mekanisme penghambatan yang melibatkan pelepasan $\gamma$-amino butyric acid. Ekstrak etanol daun kelor 
meningkatkan pertumbuhan neurit yang signifikan dalam jumlah dan panjang dendrit dan cabang akson. Hal ini menunjukkan bahwa ekstrak etanol daun kelor memberikan manfaat sebagai neuroprotektif melalui pengurangan stres oksidatif sehingga kemampuan sensori-motoris mencit dalam kondisi yang baik.

\section{Uji Kadar Malondialdehid (MDA)}

Berdasarkan tabel 4 menunjukkan bahwa perlakuan kontrol negatif mempunyai rerata konsentrasi tertinggi $(1,82 \pm 0,09)$ dibandingkan dengan kelompok kontrol posistif $(0,318 \pm 0,56)$ dan kelompok kontrol normal $(0,58 \pm 0,08)$, selanjutnya pada kelompok EEDK 100, 200, serta 400 $\mathrm{mg} / \mathrm{KgBB}$ mengalami penurunan secara berurutan. Hal ini sesuai dengan Fauzi (2008) menyatakan bahwa logam berat atau $\mathrm{Pb}$ asetat dapat menginduksi terjadinya peroksoidasi lipid. Peroksidasi lipid menghasilkan berbagai produk akhir yang bersifat radikal dan juga merusak makromolekul lain, salah satunya adalah malondialdehyde (MDA) (Winarsi, 2007).

Hasil gambar 4 menunjukkan penelitian tentang efek ekstrak daun kelor terhadap kadar MDA otak mencit yang dipapar $\mathrm{Pb}$ asetat menunjukkan adanya perbedaan rerata kadar MDA yang dihasilkan. Untuk mengetahui adanya pengaruh perlakuan, rerata kadar MDA dianalisa statistik dengan one way ANOVA satu jalur, dapat dilihat pada tabel 4.

Data kadar MDA otak mencit terdistribusi normal $p=0,242(p>0,05)$ dan homogen $p=0,338$ ( $p>0,05)$. Hasil uji ANOVA menunjukkan berbeda bermakna $p=0,000 \quad(p<0,05)$. Hal ini menunjukkan bahwa perbedaan perlakuan menyebabkan perbedaan kadar MDA otak mencit pada masingmasing kelompok perlakuan. uji LSD didapatkan hasil bahwa terdapat perbedaan bermakna antara kelompok kontrol negatif dengan kelompok

Tabel 4. Rerata \pm SD Uji Kadar MDA dan Persentase Kemampuan Menurunkan Kadar MDA

\begin{tabular}{lcc}
\hline \multicolumn{1}{c}{ Kelompok } & $\begin{array}{c}\text { Kadar MDA } \\
(\mathrm{nmol} / \mathrm{ml})\end{array}$ & $\begin{array}{c}\text { Persentase Kemampuan } \\
\text { Menurunkan Kadar MDA (\%) }\end{array}$ \\
\hline Kontrol normal & $0,58 \pm 0,08^{\mathrm{b}, \mathrm{c}}$ & 67,88 \\
\hline Kontrol positif & $0,318 \pm 0,56^{\mathrm{a}, \mathrm{c}}$ & 82,51 \\
\hline Kontrol negatif & $1,82 \pm 0,09^{\mathrm{a}, \mathrm{b}}$ & 0 \\
\hline EEDK $100 \mathrm{mg} / \mathrm{kgbb}$ & $1,52 \pm 0,06^{\mathrm{a}, \mathrm{b}, \mathrm{c}}$ & 19,61 \\
\hline EEDK 200 $\mathrm{mg} / \mathrm{kgbb}$ & $0,50 \pm 0,22^{\mathrm{a}, \mathrm{b}, \mathrm{c}}$ & 72,72 \\
\hline EEDK 400 $\mathrm{mg} / \mathrm{kgbb}$ & $0,23 \pm 0,07^{\mathrm{a}, \mathrm{c}}$ & 87,13 \\
\hline
\end{tabular}

Keterangan:[-]=ada penurunan waktu latensi, a=berbeda bermakna terhadap kontrol normal, $b=$ berbeda bermakna terhadap kontrol positif, $c=$ berbeda bermakna terhadap kontrol negatif. 
kontrol normal yang menunjukkan pemberian $\mathrm{Pb}$ asetat $50 \mathrm{mg} / \mathrm{kgBB}$ dapat menaikkan kadar MDA otak mencit. Berdasarkan hasil uji LSD juga didapatkan perbedaan bermakna antara kelompok kontrol negatif dengan kelompok kontrol positif yang menunjukkan pemberian kuersetin 50 $\mathrm{mg} / \mathrm{kgBB}$ dapat menurunkan kadar MDA. Sedangkan antara kelompok kontrol negatif dengan kelompok EEDK 100, 200 dan $400 \mathrm{mg} / \mathrm{kgBB}$ yang menunjukkan perbedaan signifikan artinya bahwa pemberian ekstrak etanol daun kelor pada dosis 100, 200 dan $400 \mathrm{mg} / \mathrm{kgBB}$ dapat menurunkan kadar MDA. Profil persentase kemampuan menurunkan kadar MDA pada EEDK dapat dilihat pada gambar 5.

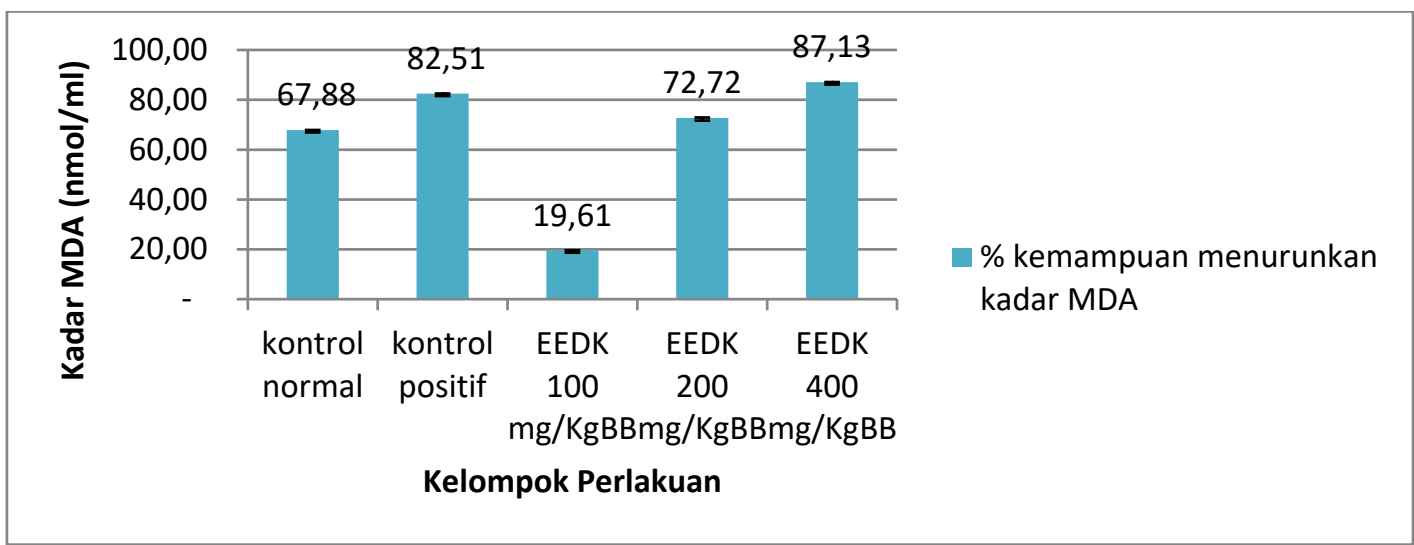

Gambar 5. Profil persentase kemampuan menurunkan kadar MDA

Persentase kemampuan menurunkan kadar MDA pada mencit yang diinduksi $\mathrm{Pb}$ asetat, EEDK 100 $\mathrm{mg} / \mathrm{kgBB}$ mempunyai persentase kemampuan $19,61 \%$ sedangkan pada EEDK $200 \mathrm{mg} / \mathrm{KgBB}$ mempunyai kemampuan $72,72 \%$ dan EEDK 400 $\mathrm{mg} / \mathrm{KgBB}$ mempunyai kemampuan $87,13 \%$. Hasil penelitian ini sesuai dengan penelitian Hacock (1999) dan Wresdiyati et al (2002) menunjukkan bahwa sifat antioksidan senyawa flavonoid dalam ekstrak etanol daun kelor bertanggung jawab untuk perlindungan terhadap stres oksidatif yang disebabkan $\mathrm{Pb}$ asetat. Pemberian EEDK sebagai antioksidan ternyata dapat berpengaruh terhadap penurunan kadar MDA yang tinggi. EEDK mengandung senyawa antioksidan yang berpotensi mengikat radikal bebas yang berlebihan. Menurut Halliwel dan Gutteridge (2000) senyawa antioksidan memiliki struktur molekul yang dapat memberikan elektronnya kepada molekul radikal bebas tanpa terganggu sama sekali fungsinya dan dapat memutus reaksi berantai. Ekstrak asetat (polifenolik) daun kelor dosis $100 \mathrm{mg} / \mathrm{KgBB}$ selama 14 hari pada tikus stres oksidatif yang diinduksi dengan $\mathrm{CCl}_{4}$ dan suplementasi dengan ekstrak daun kelor mencegah peningkatan kadar oksidasi peroksida lipid atau malondialdehid (MDA), 
Tabel 51. Rerata \pm SD dan Persentase Daya Penghambatan Jumlah Sel Piramidal hipokampus yang mengalami kerusakan di area CA1 dan CA2-CA3 otak mencit

\begin{tabular}{lcccc}
\hline \multicolumn{1}{c}{ Kelompok } & $\begin{array}{c}\sum \text { sel } \\
\text { piramidal } \\
\text { Area CA1 }\end{array}$ & $\begin{array}{c}\sum \text { sel } \\
\text { piramidal } \\
\text { Area CA2- } \\
\text { CA3 }\end{array}$ & $\begin{array}{c}\text { Persentase } \\
\text { Daya Hambat } \\
\text { kerusakan sel } \\
\text { piramidal area } \\
\text { CA1 }\end{array}$ & $\begin{array}{c}\text { Persentase } \\
\text { Daya Hambat } \\
\text { kerusakan sel } \\
\text { piramidal area } \\
\text { CA2-CA3 }\end{array}$ \\
\hline Kontrol normal & $2,00 \pm 0,71^{\mathrm{c}}$ & $2,20 \pm 0,76^{\mathrm{c}}$ & 90.00 & 87.36 \\
\hline Kontrol positif & $2,20 \pm 1,09^{\mathrm{c}}$ & $2,50 \pm 0,87^{\mathrm{c}}$ & 89.00 & 85.63 \\
\hline Kontrol negatif & $20,00 \pm 2,74^{\mathrm{a}, \mathrm{b}}$ & $17,40 \pm$ & 0 & - \\
\hline EEDK 100 & 11,80 & $1,67^{\mathrm{a}, \mathrm{b}}$ & & 27.59 \\
mg/kgbb & $\pm 2,86^{\mathrm{a}, \mathrm{b}, \mathrm{c}}$ & $1,47^{\mathrm{a}, \mathrm{b}, \mathrm{c}}$ & 41.00 & 58.62 \\
\hline EEDK 200 & $7,60 \pm 1,95^{\mathrm{a}, \mathrm{b}, \mathrm{c}}$ & $7,20 \pm 1,15^{\mathrm{a}, \mathrm{b}, \mathrm{c}}$ & 62.00 & 79.31 \\
mg/kgbb & & & & \\
\hline EEDK 400 & $2,40 \pm 0,89^{\mathrm{c}}$ & $3,60 \pm 1,59^{\mathrm{c}}$ & 88.00 & \\
mg/kgbb & & & & \\
\hline Keterangan & & & & \\
\hline
\end{tabular}

Keterangan : a=berbeda bermakna terhadap kontrol normal, b=berbeda bermakna terhadap kontrol positif, $\mathrm{c}=$ berbeda bermakna terhadap kontrol negatif.

penurunan pada konsentrasi glutathione (GSH), aktivitas superoksida dismutase (SOD) dan enzim antioksidan katalase (CAT) di hati dan ginjal (Leon et al, 2015).

Perhitungan Jumlah Sel Piramidal Hipokampus yang Mengalami Kerusakan di Area CA1 dan CA2-CA3

Pengumpulan data dilakukan dengan menghitung struktur sel piramidal yang rusak pada hipokampus. Tabel 5 di bawah ini menunjukkan rerata jumlah sel piramidal hipokampus yang rusak di area CA1 dan CA2-CA3.

Data jumlah sel piramidal di area CA1 terdistribusi normal dengan nilai signifikasinya 0,217 ( $p>0,05)$ dan uji homogenitasnya menunjukkan hasil signifikasinya 0,043 $(p<0,05)$ Analisis dilanjutkan dengan one-way ANOVA. diperoleh perbedaan yang bermakna yaitu $\mathrm{p}=0,000(p<0,05)$. Dilajutkan ke uji post hoc tamhane dengan hasil $\mathrm{p}=0,00<0,05$ yang menunjukkan bahwa adanya perbedaan perlakuan menyebabkan perbedaan jumlah sel di area CA1 otak mencit pada masingmasing kelompok perlakuan. Sedangkan data jumlah sel piramidal di area CA2-CA3 terdistribusi normal dan homogen dengan nilai signifikasinya $0,196$ ( $p>0,05)$. Analisis dilanjutkan dengan one-way ANOVA, diperoleh perbedaan yang bermakna yaitu $p=0,000(p<0,05)$. Hal ini menunjukkan bahwa perbedaan perlakuan menyebabkan perbedaan jumlah sel di area CA2-CA3 otak mencit pada masing-masing kelompok perlakuan. Berdasarkan uji Tamhane dan LSD terdapat perbedaan bermakna jumlah sel piramidal di area CA1 dan CA2-CA3 antara kelompok normal dengan 
kelompok kontrol negatif. Berdasarkan uji tamhane dan LSD data jumlah sel area CA1 dan CA2-CA3 terdapat perbedaan bermakna antara kelompok kontrol negatif dengan kelompok EEDK 100, 200 dan 400 mg/kgBB. Pada tabel 5 menunjukkan pemberian ekstrak etanol daun kelor (Moringa oleifera, Lamk) menurunkan jumlah kerusakan sel piramidal yang rusak pada kelompok EEDK 100, 200 dan 400 $\mathrm{mg} / \mathrm{KgBB}$, hal ini sesuai dengan penelitian Gajawat et al (2006) Pb mampu menginduksi radikal bebas pada mencit. Sedangkan kandungan ekstrak etanol daun kelor mampu mereda radikal bebas yang diakibatkan $\mathrm{Pb}$ asetat.

Penelitian ini juga menunjukkan persentase kemampuan penghambatan jumlah sel piramidal yang rusak pada area CA1 dan CA2CA3 otak mencit yang dapat dilihat pada gambar 6 dan 7. Bahwa kelompok EEDK $400 \mathrm{mg} / \mathrm{KgBB}$ mampu menghambat kerusakan sel piramidal hipokampus di area CA1 dengan persentase $88,00 \%$ dan CA2-CA3 dengan persentase $79,31 \%$ lebih besar dibandingkan dengan kemampuan penghambatan sel piramidal yang rusak pada kelompok EEDK 100 dan $200 \mathrm{mg} / \mathrm{KgBB}$. Sutalangka (2013) mengemukakan ekstrak daun kelor menunjukkan hasil yang signifikan dalam meningkatkan memori dan penurunan neurodegenerasi pada CA1, CA2, CA3, dan dentate gyrus dari hippocampus bersama dengan menurunkan level MDA, meningkatkan SOD, CAT, dan aktivitas asetilkolinesterase. Hannan et al (2014) dalam penelitiannya menggunakan neuron hippocampal, melaporkan bahwa penambahan ekstrak etanol daun kelor secara signifikan meningkatkan jumlah dan panjang neurit dan percabangannya, secara tergantung pada dosis, dengan konsentrasi optimal dicapai pada $30 \mu \mathrm{g}$ / ml. Ekstrak daun kelor memiliki efek positif dalam bentuk penyembuhan dan profilaksis pada toksisitas timbal (Owolabi et al, 2012).

\section{KESIMPULAN}

Ekstrak etanol daun kelor (Moringa oleifera, Lamk) dosis 100, 200 dan $400 \mathrm{mg} / \mathrm{KgBB}$ dimana dosis 400 $\mathrm{mg} / \mathrm{KgBB}$ merupakan dosis yang paling efektif dalam dapat memperbaiki memori spasial, menurunkan kadar malondialdehid (MDA), mengurangi jumlah sel piramidal hipokampus yang rusak di area CA1 dan CA2-CA3 otak mencit.

\section{UCAPAN TERIMAKASIH}

Ucapan terimakasih kepada Dr. Gunawan Pamudji W, M.Si, Apt, selaku pembimbing utama dan Dr. Jason Merari P., M.M, M.Si, Apt selaku pembimbing pendamping, yang telah bersedia meluangkan waktu, memberikan bimbingan, nasehat, ilmu dan motivasi selama penelitian ini.

\section{DAFTAR PUSTAKA}

Anwar, F., Latif, S., Ashraf, M., Gilani, A.H., 2007, Moringa oleifera Lam.: a food plant with multiple medicinal uses. Phytother Res. $21: 17-25$

Assosiasi Alzheimer Indonesia. 2003.

Konsensus Nasional

Pengenalan dan

Penatalaksanaan Demensia 
Alzheimer dan Demensia Lainnya. ed. 1, Asosiasi Alzheimer Indonesia, Jakarta

Ayala A, Munoz MF, Arguelles S. 2014. Lipid peroxidation: production, metabolism and signaling mechanism of malondialdehyde and 4- hydroxy-2-nonenal. Oxid Med Cell Longev; 112: 21-8

Bakre A.G., Aderibigbe A.O., Ademowo O.G. (2013). Studies on neuropharmacological profile of ethanol extract of Moringa oleifera leaves in mice. $J$ Ethnopharmacol, 149: 783-789.

Bannerman DM, Yee BK, Good MA, Heupel MJ, Iversen SD, Rawlins JN. 1999.Double dissociation of function within the hippocampus: a comparison of dorsal, ventral, and complete hippocampal cytotoxic lesions. Behavioral Neuroscience 113 (6), 1170-1188.

Bhagwat S, Haytowitz DB, Holden JM. 2014. USDA database for the flavonoid content of selected foods. USA:Department of Agriculture;

Butterfield, D.A., Drake, J., Pocernich, C., Castegna, A., 2001, Evidence of oxidative damage in Alzheimer's disease brain: central role for amyloid betapeptide, Trends. Mol. Med., 7, 548-554.

Erika BR, Dellima M, Sulistyawati R. 2014 Aktivitas Penangkapan Radikal Dpph Oleh Fraksi NHeksan Dan Fraksi Etil Asetat Daun Kelor (Moringa Oleifera, Lamk) Media Farmasi, Vol. 11 No. $1: 1-6$
Fauzi, T. M., 2008, Pengaruh Pemberian Timbal Asetat dan Vitamin C Terhadap Kadar Malondialdehyde dan Kualitas Spermatozoa Di dalam Sekresi Epididimis Mencit Albino (Mus Muculus L) Strain BALB/C, Tesis, Program Studi Biomedik Pascasarjana Universitas Sumatra Utara, Medan.

Gajawat, S., Sancheti, G., Goyal, P.K. 2006. Protection against leadinduced hepaticlesions in Swiss albino mice by ascorbic acid. Pharmacologyonline.1: 140149.

Gutteridge J.M.C., And Halliwell B. 2000. Free Radicals and Antioxidants in the Year $2000 \mathrm{~A}$ Historical Look to the Future Annals New York Academy Of Sciences

Halliwel, B. (2007). Dietary polyphenols: Good, bad, or indifferent for your health. Journal Cardiovascular Research, 73, 341-347.

Hancock. 1999. Lipid peroxidation-DNA Damage by Malondialdehyde. http://www.ncbi.nlm.nih.gov/ent rez/query.fcgi?cmd=Retrieve\&d $\mathrm{b}=$ PubMed\&list_uids $=1006485$ 2\&dopt=Abstract

Hannan A., Kang J., Mohibbullah M.,Hong Y., Lee H., Choi J., Choi I.and Moon S. 2014. Moringa oleifera with promising neuronal survival and neurite out growth promoting potentials. Journal of Ethnopharmacology, 152:142-150

Hebert April E., Dash Pramod K. 2004. Nonredundant roles for 
hippocampal and entorhinal cortical plasticity in spatial memory storage. Pharmacology, Biochemistry and Behavior 79 (143 - 153

Illiandri O, Widjajanto $\mathrm{E}$, dan Mintaroem K. 2010. Moringa oleifera Meningkatkan Fungsi Memori pada Tikus Model Kurang Energi Protein. Jurnal Kedokteran Brawijaya. Vol. 26 No. 1

Kale Aydemir, Pişkin Özcan, Baş Yılmaz, Aydın Bengü Gülhan, Can Murat, Elmas Özlem and Büyükuysal Çağatay. 2018. Neuroprotective effects of Quercetin on radiationinduced brain injury in rats. Journal of Radiation Research. pp. 1-7

Kirisattayakul W, Wattanathorn J, TongUn T, Muchimapura S, Wannanon $\mathrm{P}$, and Jittiwat $\mathrm{J}$. 2013. Cerebroprotective Effect of Moringa oleifera against Focal Ischemic Stroke Induced by Middle Cerebral Artery Occlusion Hindawi Publishing Corporation. Oxidative Medicine and Cellular Longevity, Article ID 951415.

Lemaire V, Koehl M, LeMoal M, Abrous DN. 2000. Prenatal stress produces learning deficits associated with an inhibition of neurogenesis in the hippocampus. Proc Natl Acad Sci USA 97:11032- 11037.

Leone A, Spada A, Battezzati A, Schiraldi A, Aristil J and Bertoli S. 2015. Cultivation, Genetic, Ethnopharmacology, Phytochemistry and
Pharmacology of Moringa oleifera Leaves: An OverviewInt. J. Mol. Sci., 16, 12791-12835; doi:10.3390/ijms160612791

Liu JT, Chen BY, Zhang JQ, Kuang F, Chen LW. 2015. Lead Exposure Induced Microgliosis And Astrogliosis In Hippocampus of Young Mice Potentially By Triggering TLR4-MyD88-NFkB Signaling Cascades. Elsevier. 239(2):97-107.

Mello CF, Kraemer CK, Filippin A, Morsch VM, Rodrigues ALS, Martins AF, et al. 1998. Effect of lead acetate on neurobehavioral development of rats. Braz J Med Biol Res. 31(7):943-50.

Meng H, Wang L, He J, Wang Z. 2016. The Protective Effect of Gangliosides on Lead (Pb)Induced Neurotoxicity Is Mediated by Autophagic Pathways. Int J Environ Res Public Health. 13(4): 365. Tersedia pada: http://www.mdpi.com/16604601/13/4/365.

Owolabi JO, Opoola E, Caxton-Martins EA. 2012. Healing and Prophylactic Effects of Moringa oleifera Leaf Extract on Lead Induced Damage to Haematological and Bone Marrow Elements in Adult Wistar Rat Models. Open Access Scientific Reports 1;(8).

Owolabi J, Williams Felicia, Fabiyi Oluseyi. 2014. Moringa's Effects Against Lead-Induced Disruption of the Hippocampus. 
World J Life Sci. and Medical Research 3(2):39

Sutalangka

Chatchada,

WattanathornJintanaporn,

Muchimapura Supaporn

andThukham-mee Wipawee.

2013. Moringa oleifera Mitigates

Memory Impairment and

Neurodegeneration in Animal

Model of Age-Related

Dementia. Hindawi Publishing

Corporation Oxidative Medicine and Cellular Longevity. Volume 2013, Article ID 695936. 9 pages

Winarsi H. 2007. Antioksidan Alami dan Radikal Bebas. Kanisius: Yogyakarta

Wresdiyati, $\quad 2004$. Imunohistokimia Antioksidan Superoksida Dismutase pada Hati Tikus Prenatal dan Postnatal. Hayati, Jurnal Biosains, (11) 3: 83-87.

Xu J, HC Yan, B Yang, LS Tong, YX Zou and $Y$ Tian. 2009. Effects of lead exposure on hippocampal metabotropic glutamate receptor subtype 3 and 7 in developmental rats. Journal of Negative Results in BioMedicine 2009;(8)5. 